\title{
"Long Live King Albany!": The History of King Lear (1608) and the Revolution in Shakespeare Studies
}

\author{
John J. Burke, Jr. \\ University of Alabama, Tuscaloosa, USA
}

\begin{abstract}
A revolution in Shakespeare studies over the past three decades asks that we take earlier quarto versions of his plays as fully independent texts. In no case can such a change in our outlook yield more illuminating results than a serious look at the 1608 Quarto version of Shakespeare's King Lear. The 1623 Folio version and the "conflated" modern editions, which combine the "best" readings of the Quarto and Folio versions, both anoint his godson Edgar, the Earl of Gloucester, as the new king at the end. However, the 1608 Quarto version elevates, not Edgar, but Lear's son-in-law, the Duke of Albany, to the kingship at the end. Shakespeare may be telling the same story in texts that seem strikingly similar, but the difference in the endings shifts the center of gravity in both plays, requiring an interpretation that makes sense out this difference. The title page of the 1608 Quarto version of King Lear describes it as a "history"; yet this "same" King Lear is listed as a "tragedy" in the 1623 Folio. The difference between those two words is the key to why Shakespeare's two versions could have startlingly different outcomes.
\end{abstract}

Keywords: Lear, Albany, Edgar, Quarto, conflated, history, tragedy

Over the past three or four decades there has been a true revolution in Shakespeare studies. In the early 20th century we passed from the 36-play canon of the First Folio, published in 1623, seven years after Shakespeare's death, to a 38-play canon which later added Two Noble Kinsmen and Pericles. At much the same time a new genre was also invented for four of the last plays, a category conspicuously absent from the First Folio. Those four plays were now to be called Tragicomedies or Romances. But no one was quite prepared for what would come in the last part of the 20th century. These earlier adjustments now look like fairly modest revolutions at best and more like mere reconfigurations. We can allow ourselves to date the major revolution that was coming from the 1986 Oxford edition of Shakespeare's works, edited by Stanley Wells and Gary Taylor. It rightly assigns a high degree of importance to the "theatricality" (as opposed to the "readability") of the texts of Shakespeare's plays, encouraging new respect for the literary value of "revisions." This new approach dissolved the time-honored tradition of only cautious use of the many Quarto versions (especially of the "bad" Quartos). This new approach has also had the practical effect of nearly doubling the number of the texts to be considered as parts of the Shakespeare dramatic canon since each version of a play was now to have its own integrity as a text.

Nowhere can the consequences of this revolution be seen more clearly than with what has happened to Shakespeare's canonical masterpiece, ${ }^{1}$ the play we call King Lear. There are now to be two plays with the

\footnotetext{
John J. Burke, Jr., Dept. of English, University of Alabama.

1 It seems worth noting that A. C. Bradley, easily among the best of commentators on Shakespeare's literary canon, offers us the following paradox: "King Lear seems to me Shakespeare's greatest achievement, but it seems to me not his best play." Shakespearean Tragedy (1904; rpt. New York: St. Martin's Press, 1985), 199.
} 
name "King Lear" in the title, not one; but both of them by William Shakespeare. The first is the 1608 Quarto version, called The History of King Lear. The second is the version that appears in the First Folio 15 years later in 1623, called The Tragedy of King Lear. Much, to be sure, has been made of the difference between the two words, "history" and "tragedy." But those two words should only succeed in drawing our attention to a far more important difference between the two versions: their last lines, those conventionally spoken at the end of the play by the character with the highest social rank, ${ }^{2}$ are in this instance spoken by entirely different characters: the last lines in the Quarto version being spoken by his eldest son-in-law the Duke of Albany whereas his godson Edgar, the new Earl of Gloucester, speaks the last lines in the Folio version even though a duke should always outrank an earl. This all important difference argues for very different political outcomes in the two versions of King Lear. It is the purpose of this paper to examine the consequences that this difference forces upon us, starting with the contention that the Duke of Albany cannot be an unimportant character.

I begin with an observation based on form. It seems rarely noticed, or at best stingily commented upon, that Shakespeare draws our attention to the Duke of Albany, husband of the royal princess Gonoril (the spelling in the 1608 Quarto differs slightly from that in the 1623 Folio version), ${ }^{3}$ by having his name mentioned at the very beginning and by elevating him to the kingship at the end of the 1608 Quarto version, signaling his importance. The Earl of Kent, in both versions, speaks the first line of the play, "I thought the King had more affected the Duke of Albany than Cornwall." Kent's observation could hardly be more bitingly ironical. Those familiar with the play are going to know in an instant that the Lear who is in his eighties could have saved himself and the people of his kingdom from much or all of the grief that is to follow if he had continued to prefer or "more affect" the Duke of Albany over the Duke of Cornwall. Not only will it become crystal clear that Albany is by far the better man of the two, it draws attention to a far more serious mistake embedded in Renaissance political lore; namely, that any plan to divide the kingdom will lead to unfortunate results. This is a mistake Lear has already made off stage, that is, before we even see him; and well before the second foolish one he will make during the love test. The second mistake will soon be dramatized before our very eyes.

This second mistake is, of course, Lear's folly in mistaking appearance for reality, a folly that will lead him to accepting his older daughters' hollow professions of love while repudiating his youngest daughter for her honesty in refusing to top their falsehoods with one of her own. A monarchy requires that there be one person at the top with the power to make the final decisions. That means Lear's initial decision to divide his kingdom equally was, quite simply, wrong-headed, contrary to all the considered and considerable experience of humankind. Division of power invites competition; competition virtually assures treachery and bloodshed. Dividing the kingdom into two parts instead of three will offer no improvement. If the play is saying anything at all, it is saying that division of power of any kind results in trouble, and almost always big trouble.

\footnotetext{
2 This may seem like nothing more than an oft-repeated truism, but this point is crucial for anyone weighing the differences between the Quarto Lear (1608) and the Folio Lear (1623). See, for example, James Shapiro, The Year of Lear: Shakespeare in 1606 (New York: Simon \& Schuster, 2015), 45.

3 There are numerous spelling differences between the Quarto and Folio versions of this play. I have yet to be persuaded that there is anything significant to be found in the difference between spelling Lear's eldest daughter's name as "Gonoril" as opposed to "Goneril." However, I do know that there are those who place great stock in the spelling of a character's name. The insistence on spelling the chief character's name in Shakespeare's Cymbeline as "Innogen" as opposed to the customary spelling as "Imogen" is but one telling instance. To those who may be annoyed by the spelling differences, my apologies, but please understand that I am hereby paying my respects in all instances to the authority of the texts. I am not following my own inclinations or preferences.

${ }^{4}$ As James Shapiro has pointed out, the use of these names, though drawn from the sources, sizzles with contemporary political significance since, for instance, King James himself once held the title of "Duke of Albany." The Year of Lear, 40.
} 
It seems worthy of note that the hints and whisperings of rivalry and conflict between the two dukes is a significant departure from what is to be found in Raphael Holinshed's account, which is generally agreed to be a major source for the story Shakespeare is retelling in this play. ${ }^{5}$ In Holinshed's account, the husbands of the two elder daughters, "Maglanus, Duke of Albania," and "Hennius, Duke of Cornwall," are indistinguishable and seemingly interchangeable in their ferocious desire to yank power from the old king. Both, contrary to what happens in Shakespeare's play, are slain at the end during the combat against the invading army from Gaul led by Lear's one true daughter Cordelia. That is but one reason that makes Shakespeare's Albany so startling a character. When we see him at the beginning of the play (and we see, but do not hear a good bit of him), he plays the role that was assigned to his counterpart in Holinshed. There is, however, a small but telling difference that occurs at the moment Lear disinherits his youngest daughter. This is the moment when Lear decides that his kingdom will now be divided into two parts instead of three as he had originally intended. At this point King Lear turns to his two sons-in-law, who will presumably be serving as regents for their royal wives, and says:

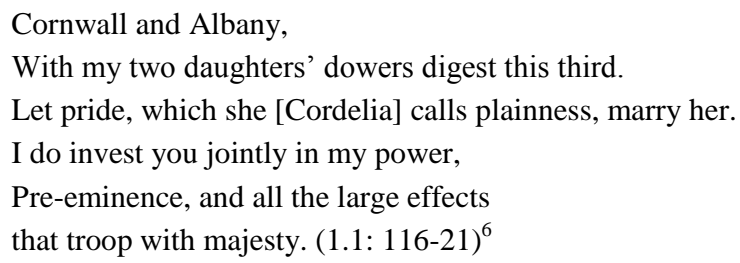

What is so surprising here, and what I believe is meant to be surprising, is that Lear addresses Cornwall first and Albany second. This is in direct contradiction to what we might expect given Kent's initial observation that Lear was generally expected to have designated Albany as his choice to rule over the kingdom. Something evidently has changed. This verbal slip seems to be indicating that Lear is now favoring the Duke of Cornwall, even if ever so slightly. We do not know what might have brought about this change, but, given what we are going to learn in the play, it seems but one more instance of how wrong Lear can be when it comes to judging those around him, even or especially his nearest and dearest.

The most important point is that it is very easy, whether reading or watching the play, to conclude that Albany is an unimportant or marginal character, one to whom not much attention needs to be paid. ${ }^{7}$ That, I

\footnotetext{
5 See Kenneth Muir on King Lear in The Sources of Shakespeare's Plays (New Haven: Yale University Press, 1978), 196-208.

6 All quotations from and citations to the Quarto text of Shakespeare's King Lear are taken from The Norton Shakespeare, ed. Stephen Greenblatt et al.; which in turn is Based on the Oxford Edition, ed. Stanley Wells and Gary Taylor. As a result, The Norton Shakespeare (New York, Norton, 1997) prints the Quarto (1608) and Folio (1623) versions of King Lear on facing pages. The Folio version is divided into acts; the Quarto version is not. Citations to the Quarto text therefore have only a number for the scene which is followed by the line numbers.

7 The number of worthwhile commentaries on Shakespeare's King Lear continues to grow. If they are not literally countless, they are close to being there. For that reason alone it seems best to cite just a few of the studies that have meant the most to me. I would begin with A. C. Bradley's discussion of Lear in Shakespearean Tragedy (1904; plus a number of reprints since); Robert B. Heilman's This Great Stage: Image and Structure in King Lear (1948; rpt. 1963); Harold Goddard's discussion of Lear in The Meaning of Shakespeare (1951; rpt. 1960); Marjorie Garber's discussion of the play in Shakespeare After All (2004). All of these could comfortably be described as "classic discussions" of King Lear which rank among the best of what has been thought and said about Shakespeare's King Lear. And yet ... all of these could also be described as "ignoring" the role of Albany in the play. Their mentions of Albany are rarely anything more than incidental. And it is certainly fair to say that, excellent as each may be, not one of them has a serious sustained discussion of Albany's importance as a character. That of course can be blamed on their use of what we now call the "conflated" text of Lear, but even in that text Albany has more importance than is typically allowed him. These classic studies, I believe, serve as mirrors of the general state of Shakespeare studies when it comes to "unimportant" characters such as the Duke of Albany. A. C. Bradley could say, generations ago, during his highly detailed discussion of Lear, the play he considered to be Shakespeare's "greatest achievement," that "Albany is merely sketched" and for that reason he has been "generally neglected" (246). Not much has changed since then.
} 
would submit, is precisely what Shakespeare wants to happen before we come to realize much later in the play just how important he truly is; unmistakably so in the Quarto text. It is certainly true that we do not see or hear much about or from the Duke of Albany for the next two acts. Our attention is almost wholly if not completely riveted on the fracturing of the two families, first that of Lear's and then that of Gloucester's. Albany plays but a bit part in all of this. The indications at first are that Albany is entirely complicit in the two elder daughters' scheme to cut their father down to size (1: 50-52). The first major hint that Albany is becoming out of sorts with the way the two daughters are treating their father, but especially his wife, comes when the Duke walks in to find his father-in-law in a rage. Lear is furious because Gonoril has let her father know that she would have him "a little to disquantify [his] train" of a hundred knights (4:228), by cutting the number in half. This was the retinue that was supposed to signify his rank and dignity; and, perhaps more importantly, it was what had been stipulated and agreed upon when he voluntarily turned over the reins of the kingdom to his daughters and their husbands. Albany insists that he had no knowledge of this betrayal and should therefore be considered "guiltless" (4: 251). What may be more revealing is his next reaction. He takes note of Lear's fury at this betrayal, and then turns towards his wife and asks, "Now, gods, that we adore, whereof comes this?" (4: 268). It is worth noting that Albany invokes the gods, indicating to us that religious piety is an important ingredient in his character. This quality aligns him with other pious believers in the play, namely Cordelia, Edgar, and Kent, but places him in opposition to the play's non-believers who most conspicuously would be Edmund, Gonoril, Regan, and Cornwall. ${ }^{8}$

The fact that Albany is not with the program or at the very least is entertaining serious reservations about it is going to bring to the surface the growing disaffection between husband and wife. Albany is going to verbalize his discomfort with the way his wife is treating her father. Gonoril will then bite back by insinuating that he is acting effeminately, allowing his womanish qualities of "milky gentleness," and "harmful mildness" (4: 309-12) to check the tough-minded actions that are required for the crisis that is upon them. At this point in the play Albany still acts with some affection toward his wife, spitfire that she may be; but it is surely in studied contrast to the disdain with which she treats him.

A new note is introduced in the scene where the Bastard, that is, Edmund, has a conversation with Curan. At this moment Edmund learns that there is "news abroad" (6: 6) that all is not well between the Dukes of Cornwall and Albany. An open conflict between the two brothers-in-law is threatening to break out at any given moment. This is telling us that the two Dukes are not at all comfortable with sharing power, reminding us once again that division of power is ever a bad idea. But Edmund is determined that it should be himself, and not his older brother, who will inherit his father's title and wealth, so he immediately and nimbly incorporates this "news" into his own plot to bring down his half-brother Edgar. Edmund tries to insinuate treasonous ideas into Edgar's head even though such ideas had not, so far as we know, ever entered his head. That plot will involve finding a way to get Edgar to run away and thus have the appearance of being indeed guilty of plotting his father's murder even though from everything we know he is entirely and completely innocent.

EDMUND. Have you [Edgar] not spoken 'gainst the Duke of Cornwall aught?

He's coming hither now, in the night, i'th' haste,

and Regan with him. Have you nothing said.

Upon his party against the Duke of Albany?

\footnotetext{
${ }^{8}$ For a detailed discussion of Shakespeare's representation of "pagan atheism," see William R. Elton, King Lear and the Gods (1966; rpt. Lexington: The University Press of Kentucky, 1988), pp. 115-146.
} 
Advise you -

EDGAR. I am sure on't, not a word. (6: 23-27)

At the beginning of Scene 8 we hear another conversation, this one between Kent and an unnamed First Gentleman, indicating that the word has been spreading through the kingdom about a division "twixt Albany and Cornwall" which is yet "covered with mutual cunning" (8: 18-20). Clearly, Kent is hoping that news of such a rift will enable Lear's friends to rally and come to his aid. Nonetheless, this will be the last that we hear or see of the Duke of Albany until a highly significant moment in Scene 16 in the Quarto (or Act 4 in the Folio version). At this point Gonoril has returned to her castle with her would-be lover Edmund at her side. She wonders, or pretends to wonder, why her husband Albany has not come out to welcome her home. Her steward Oswald is there to greet her but he has a vexed expression on his face. Oswald hastens to warn her that, as far as her husband is concerned, "never man so changed" (16: 3). Instead of "disliking" the report of the old Earl of Gloucester's treason, Albany acts as though he fully approves of it. Instead of "liking" the news that Gloucester's "treason" has been exposed by his own flesh and blood out of "loyalty" to Regan and Cornwall. He seems to find Edmund's "disloyalty" contemptible, disapproving of it, and sternly so.

The change we have only heard about in Albany becomes fully evident when he walks in and begins to talk. He has only harsh words for the wife to whom he was once so respectful, rebuking her and her sister's disrespectful treatment of their father; describing them as "tigers, not daughters" (16: 39). Albany will then go on to utter one of the play's most famous lines, for if heavens do not act quickly to right the wrongs he has heard about, then "Humanity must perforce prey on itself,/ Like monsters of the deep" (16: 48-49), and there is no mistaking who he thinks those monsters are. Gonoril then upbraids her husband, addressing him contemptuously as "Milk-livered man" (16: 49) given the threat that Britannia is now facing. This is, after all, an invasion of their native land by a foreign power. Albany in turn lets her know he is on emotional rip, ready to tear her limb from limb. He is ready to do so, but is stopped by the fact that she is a woman. Why? Because he has a very different idea of what constitutes "manliness," and doing harm to a woman is something a man with any sense of decency would never do. It is at this point that Albany gets the news about his brother-in-law Cornwall's unspeakable cruelty against the elderly and helpless elderly Gloucester and then how the Earl had been betrayed by his own son Edmund. Again, Albany "likes" the news he should "dislike" when he learns that Cornwall has paid with his own life for his criminal actions. He even vows pay-back: "Gloucester, I live / To thank thee for the love thou showed'st the King, / And to revenge thy eyes" (16: 92-94).

Albany is indeed a changed man. That, I believe, is Shakespeare's point. What we are seeing is a world where the lines between light and darkness, good and evil, moral and immoral, are clearly drawn, and there is little mistaking who is in one camp and who in the other. This world or our world does indeed generate monsters from hell which prey upon humanity. It would seem that the good characters, who are ever slow to catch on, prove to be easy pickings for the more energetic forces of evil who also happen to be immensely more intelligent; or, as we might say, just smarter. It seems as though nothing can ever stop or even check them. But it turns out there is something that can and does, and that something proves to be themselves. Having no respect for boundaries, they ever overreach. One small but telling incident occurs when Cornwall's long-time faithful servant mortally wounds his master. This is because that nameless and unnoticed servant could no longer stand to watch the heartless cruelty he had witnessed when he saw his master gouge out a helpless old man's eyes. In so many words, Cornwall is done in by his own actions. Now we are seeing the Duke of Albany, who should 
by all the customary measures be at one with his wife and his brother- and sister-in-law, now turned against them. Later in the play Albany will feel bound to apologize to Edgar for ever having believed for a moment that he or his father could have committed the crimes they were accused of (24: 172-173).

Still, Albany is not where he will be just yet. That is because he is unable yet to switch sides. As the husband of Gonoril, the eldest princess, and therefore the designated regent of Britannia he has a patriotic duty to lead the defense of his country. That means he must lead the British army against the invading army of a foreign power; in this case, France. Yet Shakespeare's decision to let Albany act in this "patriotic" fashion has led to considerable agitation among those who have commented on Albany's role in the action of the play. They argue that Albany, since he is now convinced that Lear and Gloucester have been wronged and treated with unspeakable inhumanity, should be welcoming the invading French army instead of leading the fight against them. This seems like a preposterous claim especially coming from those who are more typically expressing their distaste, even if only mildly, for the play's "virtuous" characters. ${ }^{9}$ To expect what they would have Albany do (i.e., betray his own country in the name of a "higher good") would be to expect a kind of virtuous behavior that would be far beyond the norm of human behavior as we know it, even human behavior at its best. It would be to turn Shakespeare's drama into a sugary fairy tale, and it is for sure no sugary fairy tale.

Shakespeare's point is a simple one that makes much more sense than demanding that a character in a drama act only according to the highest and most absolute standards of virtue. Albany is an important reminder, if any be needed, that most human beings (if not all) are neither all good nor all bad, neither all strong nor all weak, but ever a confusing and messy mixture of the two. As a character in a drama, Albany represents a human being on a moral journey that will lead him away from the dark side. In fact, what makes what he says and does so arresting (e.g., his outrage over the blinding of old Gloucester) is that early on in the play he was firmly connected to those who now occupy the dark side. Without quite realizing it, Albany had found himself in the midst of extraordinarily capable and intelligent people, only to find out that beyond and beneath the stimulation of their high intelligence and the charms of their pleasant exteriors, they were "monsters of the deep" ready to prey upon humanity without compunction or reservation. The action of the play shows Albany growing ever more disenchanted with these early companions, both intellectually and emotionally. However, Albany is also locked into a social and political role as the acting ruler of Britannia, and this is a role from which he cannot extricate himself.

It touches us as France invades our land;

Yet bold's the King, with others whom I fear.

Most just and heavy causes make oppose. (22: 27-29)

Albany cannot finish his journey to the right side until the final scenes of the Quarto or in those same actions placed in the fifth and final act of the Folio version. The Duke is going to lead the army of Britannia to

\footnotetext{
9 Though a number of critics and commentators have made remarks along these lines, two stand out. The first is Michael J. Warren who speaks disparagingly of Albany at points in his famous essay, "Quarto and Folio King Lear and the Interpretation of Albany and Edgar," which appeared originally in Shakespeare: Pattern of Excelling Nature, ed. David Bevington and Jay L. Halio (Newark: University of Delaware Press, 1978). pp. 95-107. Warren's essay has been widely reprinted. For some extensions of Warren's main points in that seminal essay, see The Division of the Kingdoms: Shakespeare's Two Versions of King Lear, eds. Gary Taylor and Michael Warren (Oxford: Clarendon, 1983). A second would be Steven Urkowitz in Shakespeare's Revision of King Lear (Princeton, NJ: Princeton University Press, 1980), see especially pp. 104, 121, 122, 126, 127. To be sure, Urkowitz is arguing that Shakespeare's "revision" in the Folio text which grants Edgar, and not Albany, supremacy at the end is clearly the superior version of the play.
} 
a victory over the invading army of France, in stark contrast to what we are told in Holinshed which reports a clear victory for the army of France. In Shakespeare's version, Lear and Cordelia are taken prisoner and then placed together in jail. Albany has ordered that his royal prisoners are to be treated with respect and dignity until he can make a decision about their ultimate fate. But Edmund, now Earl of Gloucester, in true Machiavellian fashion, improvises a scheme behind Albany's back to have the two royal prisoners murdered but to have the murder of Cordelia made to look like it was suicide. This is going to lead to a confrontation between the two in the last part of the play where Albany is going to take a position at the front and center of the play.

But before that happens, we have to go back to the incident that prompts this. It occurs earlier in Scene 19 of the Quarto version and in Act 4 of the Folio. Oswald has been instructed by Gonoril to deliver a letter to Edmund, the man she hunkers after as a lover and a possible husband. Her sister, the recently widowed Regan, is after the same man for herself. Regan's efforts to pry the letter from Oswald prove unsuccessful, but she sends him on his way with a new instruction that is very much to his liking: "If you do chance to hear of that blind traitor [the old Earl of Gloucester], / Preferment falls on him that cuts him off' (19: 37-38). When, then, Oswald, on his way to deliver Gonoril's letter to Edmund, happens upon the old "blind traitor," he immediately draws his sword with hopes of winning the "preferment" that Regan had promised him. However, Edgar, still disguised as a peasant, is standing nearby and comes to his father's defense. He kills Oswald. But Oswald, even as he lies dying, still plays the part of the faithful servant. With his dying breath he asks Edgar to deliver Gonoril's letter to his half-brother Edmund. Edgar finds and then opens that letter only to learn that he can now add adultery to his half-brother Edmund's other crimes. At that moment he decides to turn over the evidence of Edmund's treachery to Albany, who at this moment is, legally speaking, Edmund's commander-in-chief. Edgar also decides to use this occasion to challenge his half-brother to a trial by combat.

It is possible that Albany devours the letter that Edgar hands over to him, but the text of the play seems to suggest that he does not. He is in the middle of several crises, and barely has time to catch a breath. As the designated ruler of Britannia and commander-in-chief of her armies, he is dealing with the fall-out from their quick but unexpected victory over the invading army of France and their capture of the Queen of France and the former ruler of Britannia. What may be more stressful is that Edmund, is talking in an insubordinate tone, and that provokes a testy rebuke from Albany: "Sir, by your patience, I hold you but a subject of this war, / Not as a brother" (24: 58-60). This in turn drags to the surface the smoldering rivalry between the two sisters and prompts Regan into openly declaring Edmund to be her "lord and master" (24: 76), in effect, Albany's political equal if not his superior. This proves to be too much for Albany. At this point, he will turn on Edmund and openly accuse him of "capital treason" (24: 81). He then challenges him to trial by combat if another champion does not soon come forth. He further scolds both his wife and sister-in-law for their outrageous behavior. The unmistakable point, it seems to me, is that Albany is now acting the part of a decisive leader. His words to Edmund indicate clearly that he has anticipated new Earl of Gloucester's treachery and has taken actions that put him fully in control of a fluid and highly dangerous situation. "Trust to thy single virtue [i.e., to yourself alone], for thy soldiers, / All levied in my name, have in my name / Took their discharge" (24: 102-104). It would appear that Albany can no longer be accused of "inaction," a constant but unthinking refrain from his critics. Here, to the contrary, he acts firmly and decisively.

Albany, however, will not have to take matters into his own hands. Edgar, in yet another disguise, this one as the unknown champion, accuses Edmund, now the Earl of Gloucester, of high crimes: 


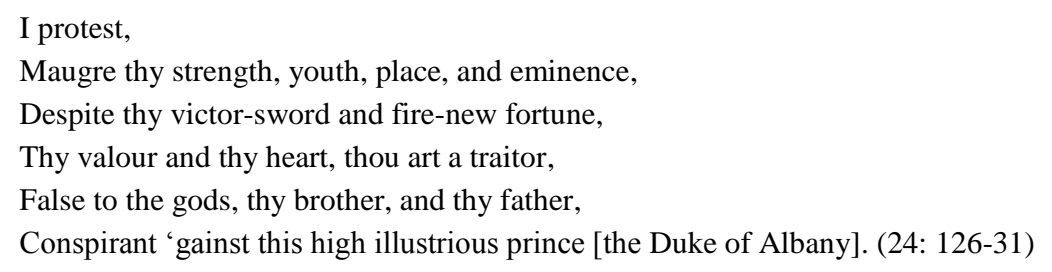

Edmund, of course, declares that everything Edgar has said is a "hell-hated lie" and therefore "treasons" themselves (24: 141-42). However, the trial by combat will prove otherwise. Evil, at least in this instance, is exposed and defeated. Edmund in his death throes will, perhaps improbably, experience a deathbed conversion. After hearing his brother's report, first on the death of their father, and then Kent's heart-breaking report on what happened to Lear after he had been cast aside and hunted down at the orders of his two older daughters, Albany will demand information about Lear and Cordelia after they were taken into custody by the forces of Britannia. Edmund will reply: "I pant for life. Some good I mean to do, / Despite my own nature" (24: 238-239). He then admits his "writ is on the life of Lear and on Cordelia" (24: 240-41). He tells those about him to take his sword as his "token of reprieve" (24: 244) to the Captain as the best way to bring a halt to the actions he had ordered. It is at this moment that Albany utters what may be his most memorable lines in hurried succession, "Run, run, O run" (24: 243), "Haste thee for thy life" (24: 246). "The gods defend her!" (24: 251). All to no avail, though. For at this very moment the unsteady old King walks in with the dead body of his beloved daughter Cordelia in his arms, a moment which has horrified readers and playgoers for centuries.

What matters now, though, is Albany's reaction to this "image of horror." At first, we watch an interchange between Lear and his faithful servant and follower, the Earl of Kent. One might expect the old King to show some gratitude for the extraordinary services Kent has rendered to him as Caius, but Lear is under terrible stress, and seems unable to process the information coming his way. We are not sure that he even recognizes Caius/Kent. What matters here, though, is that it is now over for Kent. Though Kent has only 48 years on his back, he is ready to welcome his own death, presumably as the best escape from a nightmare world. At this same moment Albany will offer to abdicate his rule. He offers "absolute power" (24: 294) to the King who had given it all away at the very beginning of the play. This has been criticized as a hollow gesture. The last thing Lear would want or need to do at this moment is to take up the burdens and responsibilities of kingship once again. But Albany is not speaking from the head, but from the heart. What may be far more important for the conclusion of the play is that Albany promises to make things right, punishing those who ought to be punished and rewarding those who have shown their merit.

[to EDGAR and KENT] you to your rights,

With boot [reward] and such addition as your honours have more than merited. All friends shall taste The wages of their virtue, and all foes

The cup of their deservings. (24: 294-298)

Just as Albany says this, Lear gives up his last breath, dying, medically speaking, from a heart attack; but, poetically speaking, from a heart that has been hopelessly fractured. Albany then turns to Kent and Edgar, offering them the "absolute power" he was going to return to Lear: "Friends of my soul, you twain / Rule in this kingdom, and the gored state sustain" (24: 313-14). But Kent lets Albany know that he is not interested: "I have a journey, sir, shortly to go: My master calls, and I must not say no" (24: 315-16). Presumably, we are to understand that Edgar, too, in this version of the play demurs. He, too, is worn out from all the trials he has 
endured. As a result he is completely uninterested in the burden of rule. That will leave the kingdom in Albany's hands. The presumption is that it is he who will become the ruler of the Britannia, no longer merely as a regent, but as its king, Lear's crown once again intact. This is the very crown that Lear's Fool had once reminded his master that he had so foolishly divided, ${ }^{10}$ as though it were nothing more than an egg (4: 138-44).

To those who would argue that the text of the play does not adequately prepare us for this stunning transformation in Albany's role, my reply would be, "Exactly!" This is where the hand of Shakespeare shows just how deft it is. The surprise we experience when we learn that the throne will pass on to Albany is, to my mind, one of Shakespeare's most telling points. The fact is the human race does not have a great scorecard when it comes to identifying, much less to predicting, which individuals will emerge to make the difference, be it for the better or for the worse. If life constantly surprises us on this count, why shouldn't the story in a great Shakespearean play do the same? Albany, too, has been stretched and drained by the play's horrors. But Albany also seems newly committed to seeing that justice must be done. That alone would make him a suitable candidate for Britannia's throne. What lies ahead is no power trip for him. He is willing to take on the heavy responsibility that will come with the throne out of a sense of duty, but only with a heavy heart. He does so, knowing full well that he will probably never have to face what the oldest (i.e., Lear and old Gloucester) have borne and knowing that if he should he could never survive such ordeals. The future, such as it will be, belongs to the young, and they must somehow or another find a way to push on.

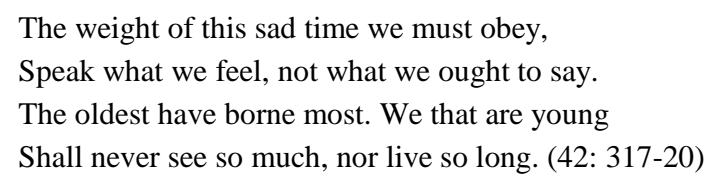

The accession of Albany, and not Edgar, is then both the most striking and the most significant difference between the Quarto and Folio versions of Shakespeare's King Lear; that is, between this play as a "history" and this play as a "tragedy." Though Albany and Edgar may seem to be characters cut from the same cloth especially near the end of the play, they started from very different places. Both are what we might call pious or religious men. More importantly, both believe that there is or there has to be a moral code that guides our actions. Both have been traumatized by wrenching betrayals, and those betrayals came from those who they had every right to think of as their nearest and dearest. Both men have become far different human beings than they were at the beginning of the play. The Folio version will elevate Edgar, though as an earl he occupies a lower rank than Albany who is a duke. The rationale for this would seem to be that Edgar, having been knocked down so low, is the one who most deserves to be raised up on high. Such reasoning has all the more force to it when we think back on Lear's scorching insight into the failures of his own kingship, one that comes when he is down and out on Salisbury Plain, cold, wet, and hungry.

Poor naked wretches, wheresoe'er you are,

That bide the pelting of this pitiless night.

How shall your houseless heads and unfed sides,

Your looped and windowed raggedness, defend you

From seasons such as these? O, I have ta'en

\footnotetext{
${ }^{10}$ For further commentary on the rich thematic meaning of Lear's "bareheadedness" after taking off his crown, see Robert Bechtold Heilman, This Great Stage: Image and Structure in King Lear (1947; rpt. Seattle: University of Washington Press, 1963), pp. 72-73.
} 
Too little care of this. Take physic [your medicine], pomp [high and mighty] Expose thyself to feel what wretches feel, That thou mayst shake the superflux to them' And show the heavens more just. (11: 25-33)

There cannot be any question about Edgar's exposure to what poor naked wretches feel after what we have seen and heard about his experiences on the lam. If Lear is right, that he would have been much better king than he ever was if he had taken seriously a monarch's obligation to look out for the welfare of all of his subjects, not just the high and the mighty, but also, and perhaps especially, to take care of the humble, the lowly, and the poor. This would make Edgar, who had been forced to survive at the very bottom of society as Tom o' Bedlam, easily the best qualified to be king. Whatever suffering Albany was forced to endure - and he was required to suffer a good deal- he never had to experience the degradation and humiliation and that Edgar was forced to endure. So, yes, by this line of reasoning Edgar would be best qualified to repair the damage that has been done to the kingdom because he knows best the damage that has been done. If order must come out of disorder in a tragedy, Edgar's elevation to the kingship can be construed as the proper ending.

Since we do not know when or how the change was made, we have to acknowledge that Albany's elevation in the 1608 Quarto is the one most likely to have been the "authorized" version. After all, the date alone tells us the 1608 Quarto was completed and published while William Shakespeare was still alive and active with the King's Men at the Globe Theater, and would have looked over what was being published in his name. Nevertheless, this version, whether authorized or not, can certainly be construed as having more to do with the Lear story as "history." First of all, as a duke, Albany outranks Edgar; that alone would place Albany next in line for succession to the throne. But there is more to it than just social rank. Albany has had genuine experience ruling; Edgar has had none. True, Albany's experience could hardly be described a joyful one. But he has served, and apparently served effectively as commander-in-chief of his nation's military forces. And more realistically, as the de facto ruler in Britannia he has had to deal with the politics of ruling. That has meant dealing with intrigue, double-dealing, backstabbing, and outright treachery, yet somehow still finding a way to come out on top. Albany has done all that. Perhaps more importantly, Albany demonstrates that he has a firm moral compass, a strong indication that he would be making every attempt he could as king to do the right thing, however difficult. The practice of history as we know it has to be more than just learning about the past just for the sake of itself. In some sense or another, it has to be about us in the present. History should have a utilitarian component, that is, knowing about the past has to in some way be helpful as we go forward. The story of the past is the most meaningful when it helps us to create the future. This is the sense of the word that I believe was important to Shakespeare. A play became a "history" when it recounted a story from out of the past that could in some way or another guide us into the future. And so, for Shakespeare's first version of the Lear story, Albany was by far best qualified to do just that as Britannia's next monarch.

Finally, it seems likely, and perhaps more than likely, that in the Duke of Albany's character Shakespeare was making a goodwill gesture towards England's recently anointed monarch, the 40-year-old King James. James had just recently succeeded Elizabeth, England's beloved Virgin Queen, who had passed from the scene in March of 1603. For England's newly crowned monarch had in his Scottish days held the title Duke of Albany. It would not be hard to see King James as a ruler who had been tested to the extreme in the political fires that flamed in late 16th-century Scotland. And that is not to mention, the monarch who in his new 
kingdom had just recently survived the terrifying Gunpowder Plot of late $1605 .{ }^{11}$ Perhaps, Shakespeare was sending an encouraging message via the play. It seems possible, perhaps even likely, he was saying (or hoping) that all such terrible experiences might, just might, have prepared the recently anointed monarch to be a better ruler over his two kingdoms. So, not "long Live, King Edgar!" as the 1623 Folio would have it, but "Long live, King Albany!" as the 1608 Quarto had it.

\section{References}

Bradley, A. C. (1985). Shakespearean tragedy. New York: St. Martin's Press.

Elton, W. R. (1988). King Lear and the Gods. Lexington: The University Press of Kentucky.

Garber, M. (2004). Shakespeare after all. New York: Pantheon.

Goddard, H. (1960). The meaning of Shakespeare. Chicago: University of Chicago Press.

Greenblatt, S. et al. (Eds.). (2009). The Norton Shakespeare: Based on the Oxford edition, $2^{\text {nd }}$ ed. New York: W. W. Norton.

Heilman, R. B. (1963). This Great Stage: Image and structure in King Lear. Seattle: University of Washington Press.

Muir, K. (1978). The sources of Shakespeare's play. New Haven: Yale University Press.

Shapiro, J. (2015). The Year of Lear: Shakespeare in 1606. New York: Simon Schuster.

Taylor, G., \& Warren, M. (Eds.). (1986). The division of the Kingdoms: Shakespeare's two versions of King Lear. Oxford: Clarendon Press.

Urkowitz, S. (1980). Shakespeare's revision of King Lear. Princeton, NJ: Princeton University Press.

Warren, M. (1978). Quarto and Folio King Lear and the Interpretation of Albany and Edgar. In Shakespeare: Pattern of excelling nature (pp. 95-107). Newark: University of Delaware Press.

${ }^{11}$ For a well-informed account of the Gunpowder Plot from a Shakespearean perspective, see James Shapiro's account in The Year of Lear, 89-179. 